\title{
Development of the Information System Structure for Continuous Improvement of QMS in an Educational Institution
}

\author{
Ekaterina Men'shikova $^{1}$, Oleg Khazanov ${ }^{2}$, Marina Verkhovskaya ${ }^{1, a}$ \\ ${ }^{1}$ Tomsk Polytechnic University, 634050 Lenin Avenue, 30, Tomsk, Russia \\ ${ }^{2}$ Tomsk State University, 634050 Lenin Avenue, 36, Tomsk, Russia
}

\begin{abstract}
The paper describes information technologies and their applications to improve the efficiency of the organization. The use of information technologies for improving the quality management system (QMS) of the educational institution is shown. Internal and external information flows within the QMS of educational institutions based on the example of Tomsk polytechnic university (TPU) are described. The structure of information flows for basic processes of TPU activities in QMS is developed. A practical impact of the information system on continuous improvement of QMS in TPU is demonstrated.
\end{abstract}

\section{The role of information technology in QMS of educational institution}

The use of information technologies (IT) increased the potential of companies in more effective product and service quality management, contributing to the improvement of technological process, compliance with requirements and standards and maximizing customer satisfaction. Thus, the application of IT becomes relevant for QMS improvement in educational institutions. Information systems development and computerization in the modern educational system are focused on development of optimal conditions for satisfaction of information needs of objects and subjects of the educational process, based on formation and use of information resources. Moreover, the technical support base for information processing and storing is being developed.

In the study of the question posed the following methods were used: the methods of structural and system analysis.

The aims and objectives of the application of IT in the QMS of educational institutions are: more effective management of the information process; improving the quality and effectiveness of the decisions in the field of quality of educational services management; more effective management (registration, storage, processing and transmission) of information resources of educational institutions; ensuring the effective integration of heterogeneous information resources from various sources in the information system of QMS; improving the efficiency of information interaction of all stakeholders in the field of quality assurance in educational institutions.
Accordingly, the information and technology support for QMS can rely on the existing organizational software. It can be customized to reflect processes of the life cycle, which affect quality. It can additionally record the results of operations for the collection, recording and processing of data (records and quality reports). However, from our point of view, the main tasks of introduction of information technologies in QMS are tasks of "processes organization", support for "system and process approaches", as the organization's management methods - management - are built on the principles of quality management.

While introducing IT in QMS in an organization there many general questions and challenges. Since the amount of information is enormous and beyond perception ability, it is possible to accomplish the following tasks: rational organization of information flows, selection and processing of information relevant to the activities of the company.

Enterprise information environment is determined by a specific type of resource support of the processes information resource of the management system. Any organization is a system, operating on the basis of information links, which can be represented as a system of organization of internal and external flows, as well as methods and tools of search, processing and distribution of information in the organization [1].

Let us consider internal and external information flows within the QMS of educational institutions (EI).

Internal information flows are:

- information about the organizational structure, including organizational units, their responsibilities, functions, composition;

- description of the process;

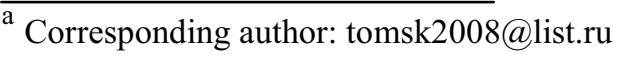


- data and information about educational services and scientific research, implemented by an organization;

- data on raw materials and the information processed in the framework of processes;

- information on the resources required for the implementation of processes, including manpower, technologies, equipment, organizational structure, etc.;

- rules and procedures used in the implementation of processes;

- rules and procedures for quality control of processes and products;

- information and data collected by the organization in the system of knowledge management;

- indicators used to assess and analyze the effectiveness and efficiency of processes and relevance of services provided;

- data obtained as a result of the process audits and their quality control;

- initiatives and projects to improve the individual processes;

- QMS documents, such as a guide to the quality of the organization, programs and quality plans, documented procedures, job descriptions, regulations and standards, quality records, etc.;

- other administrative decisions and administrative documents generated and processed as part of the QMS.

In addition, internal information flows of an organization are divided by types of knowledge circulating in the organization. Sources of internal information flows according to the types of knowledge are presented in (Table 1).

Table 1: Internal sources of information by types of knowledge

\begin{tabular}{|c|c|}
\hline Types of knowledge & Sources of Information \\
\hline $\begin{array}{l}\text { Empirical knowledge } \\
\text { (observations, } \\
\text { observed } \\
\text { phenomena) }\end{array}$ & $\begin{array}{l}\text { The results of studies of } \\
\text { organizational and psychosocial } \\
\text { factors; multifactorial analysis of } \\
\text { the enterprise; results of the } \\
\text { statistical analysis of the } \\
\text { enterprise; indicators of products } \\
\text { renewal; service, nomenclature. } \\
\text { Strategic plans and long-term } \\
\text { forecasts of the enterprise. } \\
\text { Indicators of defects; the level of } \\
\text { industrial labor; fulfillment of } \\
\text { work norms; staff turnover rates } \\
\text { and retirement. }\end{array}$ \\
\hline $\begin{array}{l}\text { Theoretical } \\
\text { knowledge (laws, } \\
\text { theories, } \\
\text { abstractions, } \\
\text { generalizations) }\end{array}$ & $\begin{array}{l}\text { Internal organizational and } \\
\text { regulatory support: enterprise } \\
\text { policy, the charter of the } \\
\text { enterprise, an organizational } \\
\text { structure, orders, regulations, } \\
\text { instructions on general rules of } \\
\text { labor protection and fire safety; } \\
\text { instructions for employees; etc.). } \\
\text { The quality management system, } \\
\text { quality policy. Technical } \\
\text { assignments, processes, the results } \\
\text { of research and development, a } \\
\text { business process map. }\end{array}$ \\
\hline
\end{tabular}

\begin{tabular}{|c|c|}
\hline $\begin{array}{l}\text { Organizational } \\
\text { knowledge } \\
\text { (theoretical } \\
\text { knowledge of a } \\
\text { particular field of } \\
\text { activity, } \\
\text { technological and } \\
\text { industrial standards, } \\
\text { rules and regulations, } \\
\text { business knowledge). }\end{array}$ & 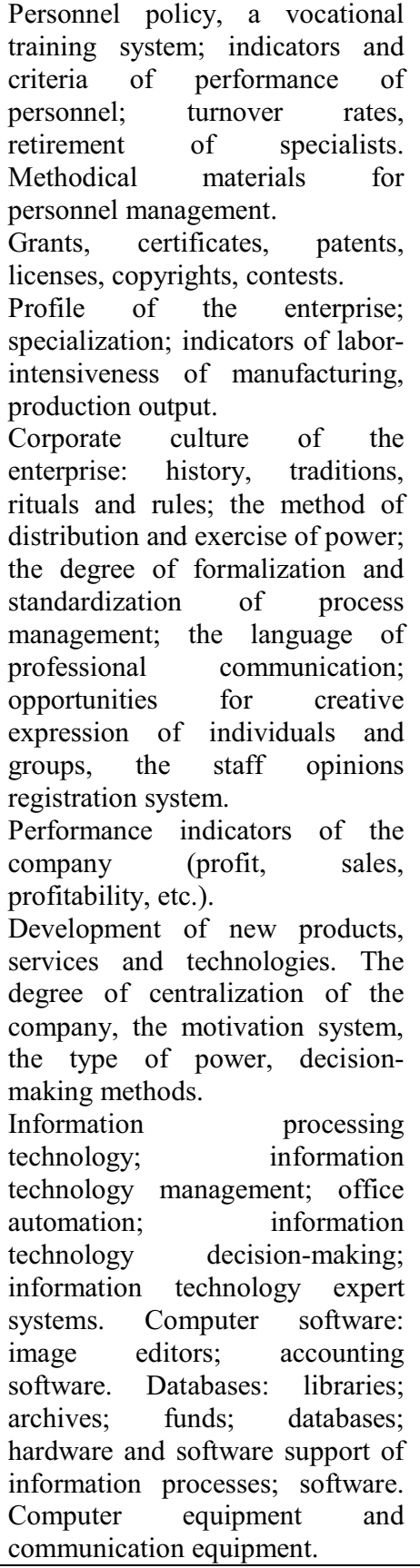 \\
\hline
\end{tabular}

External information flows:

- data and information obtained during marketing research of the potential consumers of educational services, their needs and expectations;

- information on existing educational programs;

- information on employers' databases;

- information on strategic partnership with leading universities;

- information from career building services with potential customers;

- information from open sources (mass media and the Internet);

- analytical surveys;

- feedback from customers;

- state educational standards, programs, etc. 
If we use a system approach and consider a university as an open educational system, the following subsystems of the information system can be distinguished [3]: an educational subsystem; an administrative subsystem; a science subsystem; a supporting subsystem.

For the effective functioning of these subsystems it is necessary to develop and implement hardware and software that provides information support and correct transmission of information between the subsystems.

The components of information technology, currently used in universities include:

- scientific and educational portals that provide access to a global information resources through the university, as well as access to internal information resources of the university;

- distance learning systems, which ensure export of educational processes in the external environment;

- systems of university document automation for management of administrative information;

- network technology, providing access to global information resources for the university.

For the effective functioning of these components it is necessary to use three levels of administration:

- a lower level - network administration;

- a middle level - administration of distance learning and administration document management system;

- an upper level - administration of the research and education portal.

As information flows permeate all areas of the EI, the

following components are always present in this process:

- management of the educational process;

- management of scientific activity;

- general administration and management;

- information and methodical support of the educational process;

- monitoring of the educational process;

- implementation of the educational process.

Now let us consider the structure of information flows in TPU, reflecting the basic processes of educational activity (Table 2 ).

Table 2. The structure of information flows in TPU for core activities

\begin{tabular}{|l|l|l|}
\hline $\begin{array}{l}\text { Areas of activity } \\
\text { TPU }\end{array}$ & Processes & Information flows \\
\hline $\begin{array}{l}\text { 1. General } \\
\text { administration } \\
\text { and } \\
\text { management }\end{array}$ & $\begin{array}{l}\text { 1.1. Admission } \\
\text { organization in } \\
\text { TPU }\end{array}$ & $\begin{array}{l}\text { Applications by } \\
\text { forms and levels of } \\
\text { education. } \\
\text { Admission orders } \\
\text { for students in TPU. }\end{array}$ \\
\cline { 2 - 3 } & $\begin{array}{l}\text { 1.2. Planning and } \\
\text { organization of } \\
\text { the educational } \\
\text { process. }\end{array}$ & $\begin{array}{l}\text { Federal State } \\
\text { Educational } \\
\text { Standards (FSES) } \\
\text { of the third } \\
\text { generation of all } \\
\text { forms of education. } \\
\text { Annual educational } \\
\text { plans, staffing. }\end{array}$ \\
\cline { 2 - 3 } & $\begin{array}{l}\text { 1.3. Organization } \\
\text { of faculty work }\end{array}$ & $\begin{array}{l}\text { Annual educational } \\
\text { teachers load. } \\
\text { Annual methodical, } \\
\text { scientific, }\end{array}$ \\
\hline
\end{tabular}

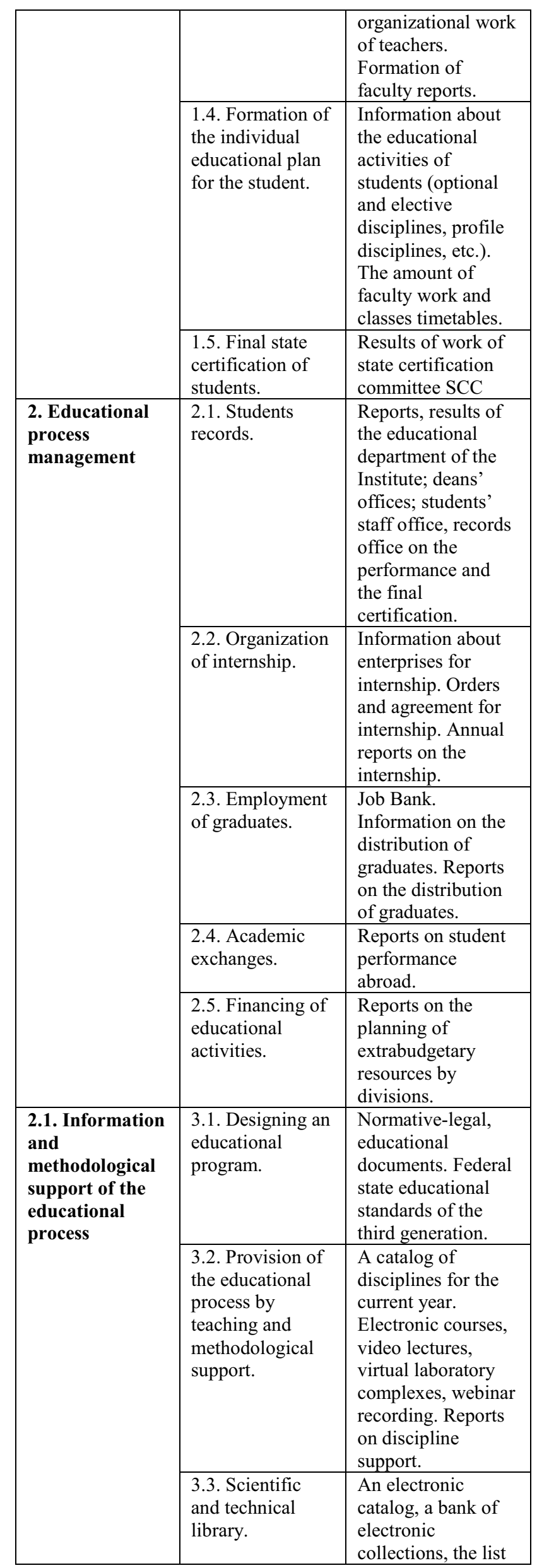




\begin{tabular}{|c|c|c|}
\hline & & $\begin{array}{l}\text { of teachers' } \\
\text { publications, } \\
\text { ordering books } \\
\text { online. }\end{array}$ \\
\hline & $\begin{array}{l}\text { 3.4. The system } \\
\text { of TPU portal } \\
\text { sites. }\end{array}$ & $\begin{array}{l}\text { Websites: } \\
\text { "Entrant", } \\
\text { "Student", } \\
\text { "Employee", } \\
\text { personal students' } \\
\text { accounts, personal } \\
\text { teachers' accounts, } \\
\text { departments } \\
\text { websites, personal } \\
\text { websites. }\end{array}$ \\
\hline \multirow[t]{3}{*}{$\begin{array}{l}\text { 2.2. Monitoring } \\
\text { of the } \\
\text { educational } \\
\text { process }\end{array}$} & $\begin{array}{l}\text { 4.1. Current and } \\
\text { in-session } \\
\text { performance. }\end{array}$ & $\begin{array}{l}\text { Data on the current } \\
\text { and sessional } \\
\text { academic } \\
\text { performance of } \\
\text { students. }\end{array}$ \\
\hline & $\begin{array}{l}\text { 4.2. Reporting on } \\
\text { contingent. }\end{array}$ & $\begin{array}{l}\text { University } \\
\text { departments' } \\
\text { reports. }\end{array}$ \\
\hline & 4.3. Supervision. & $\begin{array}{l}\text { Information on } \\
\text { consultants, of } \\
\text { supervised students. }\end{array}$ \\
\hline \multirow[t]{2}{*}{$\begin{array}{l}2.3 . \\
\text { Implementation } \\
\text { of the } \\
\text { educational } \\
\text { process }\end{array}$} & $\begin{array}{l}\text { 5.1. e-learning } \\
\text { organization. }\end{array}$ & $\begin{array}{l}\text { The planned } \\
\text { schedule of the } \\
\text { discipline. } \\
\text { Electronic database } \\
\text { of tests for the } \\
\text { input, current and } \\
\text { final control. } \\
\text { Electronic } \\
\text { "Webinar"; } \\
\text { "Forum"; LMS } \\
\text { «Moodle». }\end{array}$ \\
\hline & $\begin{array}{l}\text { 5.2. Organization } \\
\text { of project work. }\end{array}$ & $\begin{array}{l}\text { Electronic database } \\
\text { of methodical } \\
\text { support of creative } \\
\text { projects of students. }\end{array}$ \\
\hline \multirow[t]{3}{*}{$\begin{array}{l}\text { 3. Scientific } \\
\text { activity } \\
\text { Management }\end{array}$} & $\begin{array}{l}\text { 3.1.Formation of } \\
\text { the priority areas } \\
\text { of research and } \\
\text { innovation }\end{array}$ & $\begin{array}{l}\text { Information from } \\
\text { open sources (mass } \\
\text { media, the Internet). } \\
\text { Analytical reviews. }\end{array}$ \\
\hline & $\begin{array}{l}3.2 \text { Research and } \\
\text { development }\end{array}$ & $\begin{array}{l}\text { Information about } \\
\text { the methods of } \\
\text { creation of new } \\
\text { products and } \\
\text { processes. Programs } \\
\text { and methods of } \\
\text { layouts testing. } \\
\text { Information on } \\
\text { implementation and } \\
\text { use of research } \\
\text { results. }\end{array}$ \\
\hline & $\begin{array}{l}\text { 3.3. Production of } \\
\text { high-tech } \\
\text { products }\end{array}$ & $\begin{array}{l}\text { Information on } \\
\text { technical design } \\
\text { specification, } \\
\text { contracts, customer } \\
\text { contracts. } \\
\text { Operating } \\
\text { Instructions (for the } \\
\text { equipment). } \\
\text { Certificate of } \\
\text { completion. }\end{array}$ \\
\hline
\end{tabular}

\begin{tabular}{|l|l|l|}
\hline & $\begin{array}{l}\text { 3.4. Training of } \\
\text { highly qualified } \\
\text { personnel }\end{array}$ & $\begin{array}{l}\text { The results of } \\
\text { entrance } \\
\text { examinations. } \\
\text { The order of } \\
\text { admission to post- } \\
\text { graduate / doctoral } \\
\text { studies. } \\
\text { Annual analysis of } \\
\text { scientific activity. } \\
\text { Data on the number } \\
\text { of post-graduate / } \\
\text { doctoral thesis } \\
\text { submitted in time. }\end{array}$ \\
\hline
\end{tabular}

\section{Conclusion}

Thus, in this paper we have considered the potential of information technologies and their applications to improve the efficiency of the enterprise. A description of the place and role of information technologies, especially their use for improving the QMS of the educational institution is given.

The above-mentioned information resources of the management system are viewed as specific kinds of resources that support the processes in the organization. They can be represented as a system of organization of flows of internal and external information.

A description of the internal and external information flows within the quality management system of educational institutions (using TPU as an example) is provided. These flows enable effective management of the organization.

From a systems perspective, considering the university as an open educational system, we allocated subsystems of TPU Information System: education, administration, scientific and support subsystems.

In this paper the components of information technologies used in TPU are also identified and described. They make it easy to solve problems of storage, retrieval and delivery of information to consumers of educational services. They also provide access to both internal and external information resources of the university, enable export of educational processes to external environment.

Dedicated components of information technologies act as an extensive storage of information resources in the educational institution. They provide new opportunities for the creation, dissemination and application of multicomponent distributed and integrated databases and knowledge, focused on education. IT permeates all areas of EI (teaching, research, administration, etc.)

We have considered information flows in the context of basic processes of activity in TPU in QMS. The presented structure of the information system will ensure continuous improvement of the QMS in TPU.

Thus, identification of an information flow based on the main types of TPU activities allowed creating a student-centered educational environment, the main elements of which are the creation of a personal account for students and university staff on a portal of TPU, and 
focused efforts on the implementation of international concept (standards) CDIO.

\section{References}

1. L.N. Kechiev, G.P. Putilov, S.R.Tumkovsky, Op. Edu, 2, 34-42 ( 2002)

2. I.E. Kryukov, V.A. Matyushin, A.D. Shadrin, V. Q., 3, 34 (2003)

3. V.I. Soldatkin, Univ. Man.: Prac. and Anal., 4, 1417 (2001)

4. P. Abraham, L.Suganthi, In. Jo. Of Pr. and Q. M, 12 (3), 287-312 (2013)

5. A.W. El-Morsy, H. Shafeek, A. Alshehri, S.A. Gutub, L. S. J., 11 (8), 119-125 (2014)

6. I. Mustapha, A. Jusoh, , K.M. Nor, J. T., 72 (4), 712 (2015)

7. A. Razzaque, A. Jalal-Karim, Proc. of the Eur., Med. Conf. on I. S., EMCIS (2010) 